\title{
On an attempt to Explore the Possible Challenges Faced by Upcoming and Established Photographers in India and Studying the Interrelationships using ISM Methodology
}

\author{
Lakshay Aggarwal \\ Sociobuddy Technologies Private \\ Limited, \\ Delhi, India
}

\author{
Remica Aggarwal \\ MIT School of Education \& \\ Research, \\ MIT Art, Design \& Technological \\ University \\ Pune, India
}

\author{
V. K. Aggarwal \\ Recventures Education Services \\ Private Limited \\ Delhi, India
}

\begin{abstract}
Present research paper makes an exploratory study about the various challenges faced by different category of photographers such as professional photographers, landscape photography and freelance photographers.
\end{abstract}

\section{Keywords}

Interpretive Structural Modeling Methodology, MIC -Mac Analysis, Photography, Photography challenges, Landscape photography, Freelance photography

\section{INTRODUCTION}

Every category of content creator faces serious challenges these days whether it is content writer, script writer, e-book content writer etc. No matter what copyright industry you look at, internet has provided a hybrid basket of opportunities and challenges. As the time speed up, challenges are becoming more severe and opportunities are condensing. The challenge photographers face isn't just one of piracy or people trying to get work for free rather it could be said that online photography and along with it its extensions such as visual arts have become, to many, almost temporary and non-refundable. Various social media platforms such as Pinterest, Facebook, Youtube etc. are quite popular and are actively used by both the professional photographers as well as amateurs for posting their work either free or on purchase

The present research focuses on exploring various types of challenges which are faced by professional photographers , landscape photographers as well as freelance photographers. This are explained in section 2 . Thereafter managerial implications are presented in section 3.

\section{AN EXPLORATION OF THE BASIC CHALLENGES BEFORE THE PHOTOGRAPHER}

\subsection{Challenges before a professional photographer are $[1,2]$ :}

2.1.1. The Copyright and Piracy Problem (CPP) : Image infringement is a well-known challenge before any photographer. Some of the photographers actively share their work with audiences whereas in many cases often the photographs posted on net gets easily copied owing to their small file size and therefore they are easy to share. It is much easier to share and distribute a photo than it is a movie or song
A major drawback is these photo sharing sites do not uses any algorithms to prevent re-uploading of infringing images. But then there are audiences who would never dream about illegally downloading a movie or an album or even sharing an artist's photograph without his/her permission.

2.1.2 Advancement in Mobile technology (AMT) : With the advent and widespread use of high quality cell phone cameras, it has become quite difficult for a non-photographer to tell the difference between a photo snapped in a few seconds on an iphone from a photo that took hours of work in a studio or preparation in field. This has the side effect of making photographs appear temporary and disposable, like text messages or Facebook status updates. They often appear have no real long term value, artistic or otherwise.

2.1.3. Attribution issues (AT): Resolving the attribution issue is fairly simple if a photographer is willing to make sure that none of their photos are posted online without a watermark. While many understandably oppose watermarks because they alter the image in an unpleasant way, a photo shared without attribution does little good to the person who took it.

2.1.4. Finding new clients (FNC): The most worried-about thing is the task of finding new clients - something $74 \%$ of photographers said was their top challenge.

2.1.5. Amount of investing money (AIM) : As per a survey report nearly half of the old or new photographers invest money in photography lessons and workshops apart from spending in purchasing equipment or camera parts. Workshops and courses geared toward improving your photography and business are apparently very in-demand these days.

\subsection{Challenges for a landscape photographer 3}

Landscape photography allows the photographer to capture the amazing scenes of nature in a photograph. This could be cherish afterwards and loving memories are created. However, there are many challenges that you will face and need to overcome, as a landscape photographer. These challenges could relate to the surrounding nature and are described as follows:

2.2.1. Unpredictable Weather (UW): One of the realities of landscape photography is that you have no control over the weather. Maybe you want to photograph the sunset, but it's 
rainy and overcast with no sun visible. Or maybe you want to photograph a beautiful waterfall secluded in a forest, but harsh sunlight is making the scene less than ideal. Or perhaps a thunderstorm or snowstorm is making it hard, or even dangerous, to be out.

2.2.2. Limited Windows of Time (LWT): The hours around sunrise and sunset are obviously favourites for landscape photographers. The challenge is that these windows of time with the best light are limited, and you need to be ready to make the most of them. Plan ahead so you know when the sun will rise and set, and from what angle. It is usually expected to spend some time at the location and to reach well before time before you pack up when the work is done.

2.2.3. Capturing a Scene as it Appears to the Eye (CS) : The scene captured by the camera will not always equal what you saw with your eyes. The dynamic range captured by camera sensors has improved a lot in recent years, but there are still times when a scene has too much range between the shadows and highlights. This is especially common around sunrise and sunset. It can also be an issue when photographing a forest, a canyon, or other scenes with deep shadows.

2.2.4. Finding Places to Photograph (FPP) : Simply finding places to photograph can also be a challenge. There are a lot of ways you can go about finding locations in your area . Resources such as finding photograph in the related area on Flickr or joining a photography forum helps. Other than that there are websites and blogs that serve as a great source of information on the unknown locations

\subsubsection{Creating Interesting Photos at Popular Locations} (CPPL) :

A trip to well-known, epic location can be a great experience for a landscape photographer. While these epic locations are usually popular for good reason, clicking a " hatke" picture could be challenging. In many cases, with a little bit of hiking and some effort, you can easily find unique opportunities even in popular locations. Most people stick to the easy views, so if you're willing to work and take the time to go somewhere most people don't go, you can get different views and find new subjects.

2.2.6. Patience (Pa) / Lack of patience (LoP) : Whether it is waiting for the right light or weather conditions, right timing or the right location, patience is always a challenge. Keeping your calm and adjusting yourself to the situation that nature's tasks are beyond human control will help. Try to enjoy being surrounded by nature even if the favourable opportunities are missing .

2.2.7. Trying to be Perfect / Lack of perfection (LP): Amazing photos have been clicked by very skilled hands who have spent years developing their skills so best policy is to avoid disappointment if the photographs are not as good as expected .

\subsection{Challenges before a Freelance photographer 4}

Following are challenges faced by freelance photographer :

2.3.1.Working alone (WA) : When you become for the first time a freelance photographer, you turned into an introvert. You are quite disconnected to society. Not at all or very little socialise . Introvert works best as photographers because they want to be focused .

2.3.2. Inconsistent income (II) : This is probably one of the biggest challenge. Because when you become the photographer, it is hard to predict or know how much money will you

be earning each month. This is determined by the consistency of work and project as well as the number of clients you have Inconsistent incomes as a freelancer made it difficult to make certain plans financially because there is no telling whether you will have the same income the following month. Solution to this could be putting your corporate clients who can actively hire you for a month as a retainer per month.

2.3.3. Always hustle (AH) : As a freelancer, you are always hustling to get and trying to recruit new clients. You should inculcate that talent to generate the idea on the spot and should be able to sell that idea on the spot to the person who could become your potential customer.

With the understanding that time is money for a freelancer, you should be able to utilize the time you have in the best possible way . Sometime people force themselves to a point where they may not be doing the work with passion but as a project who can generate some income to pay the bills.

2.3.4. Distractions (Di) : Most of the people are a huge victim of this. As a freelancer, you are your own boss which means you set your own rules and your own work hours However, most of us are not as disciplines and often look for many things and thereby end up doing thousands of other things and get distracted from doing the job or project they are getting paid to. Some people do have supervisors to keep them on time.

\section{INTERPRETIVE STRUCTURAL MODELLING METHODOLOGY}

Warfield [25] proposed the ISM technique in 1994. Following the process results in creating a structured graph from the set of unique interrelated variables. The process goes through the various steps viz. identifying the relevant elements and establishing a contextual relationship amongst them; then an Structural self- interaction matrix is developed to establish the lead to relationship amongst the two variables $i \& j$. An initial reachability matrix is then created which eventually leads to the development of final reachability matrix and thereafter reachability set and antecedent set for each criterion. In every iteration a top level element is selected for which the reachability set and intersection sets are the same.

\section{DEVELOPMENT OF ISM MODEL}

In this section, ISM model is developed for studying the interrelationships amongst various collective possible challenges faced by upcoming and established photographers in India. Around 14 such challenges have been identified in section $2 \mathrm{viz}$. Copyright and piracy problem (CPP); Advancement in mobile technology(AMT) ; Attribution issues (AT) ; Difficulty in finding new clients (DFNC) ; Shortage in terms of investing money in professional photography (SIM) ; Problem in finding places to photograph (PFPP); Problem in creating interesting photographs (PCIP) ; Limited time period (LTP) ; Lack of patience (LoP); Lack of perfection (LP); Working alone (WA); Inconsistent income (II) ; Always hustle $(\mathrm{AH})$; Distraction (Di) .

\subsection{Construction of Structural Self - Interaction Matrix (SSIM)}

This matrix gives the pair-wise relationship between two variables i.e. $i$ and $j$ based on VAXO. SSIM has been presented below in Fig 1 . 
Explanation : Problem in finding unique location or appropriate places to photograph do result in attribution issues and therefore it is suggested that photographers do use watermarks in their picture click. Investment problems also force you to work alone. Also the limited time period to click photographs do affect the quality of photograph clicked as well as result in distraction and create hustle. Inconsistent income may force you to work alone. To avoid distraction , some choose to work alone in photography. Same is true with keeping the inconsistent income in check. Advancement in mobile technology may create lack of patience.

\subsection{Construction of Initial Reachability Matrix and final reachability matrix}

The SSIM has been converted in to a binary matrix called the initial reachability matrix shown in fig. 2 by substituting $\mathrm{V}, \mathrm{A}$, $\mathrm{X}, \mathrm{O}$ by 1 or 0 as per the case. After incorporating the transitivity, the final reachability matrix is shown below in the Fig 3.

Fig 1: SSIM matrix for pair wise relationship amongst barriers

\begin{tabular}{|c|c|c|c|c|c|c|c|c|c|c|c|c|c|c|c|}
\hline $\begin{array}{c}\text { S. } \\
\text { No. }\end{array}$ & Barriers & 1 & 2 & 3 & 4 & 5 & 6 & 7 & 8 & 9 & 10 & 11 & 12 & 13 & 14 \\
\hline & & CPP & AMT & AT & DFNC & SIM & PFP & PCIP & LTP & LoP & LP & WA & II & AH & Di \\
\hline 1 & CPP & & A & X & V & A & O & X & O & O & V & A & A & A & A \\
\hline 2 & AMT & & & V & V & X & O & V & O & V & V & V & V & V & V \\
\hline 3 & AT & & & & V & A & A & X & O & A & A & A & A & A & A \\
\hline 4 & DFNC & & & & & A & A & A & O & A & A & A & A & A & A \\
\hline 5 & SIM & & & & & & V & V & O & V & V & V & A & V & V \\
\hline 6 & PFP & & & & & & & X & V & V & V & V & A & A & X \\
\hline 7 & PCIP & & & & & & & & A & A & A & A & A & A & A \\
\hline 8 & LTP & & & & & & & & & V & V & A & X & V & V \\
\hline 9 & LOP & & & & & & & & & V & V & V & V & V \\
\hline 10 & LP & & & & & & & & & & V & V & V & V \\
\hline 11 & WA & & & & & & & & & & & A & A & A \\
\hline 12 & II & & & & & & & & & & & & & V & V \\
\hline 13 & AH & & & & & & & & & & & & & & V \\
\hline 14 & Di & & & & & & & & & & & & & \\
\hline
\end{tabular}

Fig 2: Initial reachability matrix

\begin{tabular}{|c|c|c|c|c|c|c|c|c|c|c|c|c|c|c|c|}
\hline $\begin{array}{c}\text { S. } \\
\text { No. }\end{array}$ & Barriers & 1 & 2 & 3 & 4 & 5 & 6 & 7 & 8 & 9 & 10 & 11 & 12 & 13 & 14 \\
\hline & & CPP & AMT & AT & DFNC & SIM & PFP & PCIP & LTP & LoP & LP & WA & II & AH & Di \\
\hline 1 & CPP & 1 & 0 & 1 & 1 & 0 & 0 & 1 & 0 & 0 & 1 & 0 & 0 & 0 & 0 \\
\hline 2 & AMT & 1 & 1 & 1 & 1 & 1 & 0 & 1 & 0 & 1 & 1 & 1 & 1 & 1 & 1 \\
\hline 3 & AT & 1 & 0 & 1 & 1 & 0 & 0 & 1 & 0 & 0 & 0 & 0 & 0 & 0 & 0 \\
\hline 4 & DFNC & 0 & 0 & 0 & 1 & 0 & 0 & 0 & 0 & 0 & 0 & 0 & 0 & 0 & 0 \\
\hline 5 & SIM & 1 & 1 & 1 & 1 & 1 & 1 & 1 & 0 & 1 & 1 & 1 & 0 & 1 & 1 \\
\hline 6 & PFPP & 0 & 0 & 1 & 1 & 0 & 1 & 1 & 1 & 1 & 1 & 1 & 0 & 0 & 1 \\
\hline 7 & PCIP & 1 & 0 & 1 & 1 & 0 & 1 & 1 & 0 & 0 & 0 & 0 & 0 & 0 & 0 \\
\hline 8 & LTP & 0 & 0 & 0 & 0 & 0 & 0 & 1 & 1 & 1 & 1 & 0 & 1 & 1 & 1 \\
\hline 9 & LoP & 0 & 0 & 1 & 1 & 0 & 0 & 1 & 0 & 1 & 1 & 1 & 1 & 1 & 1 \\
\hline 10 & LP & 1 & 0 & 1 & 1 & 0 & 0 & 1 & 0 & 0 & 1 & 1 & 1 & 1 & 1 \\
\hline 11 & WA & 1 & 0 & 1 & 1 & 0 & 0 & 1 & 1 & 0 & 0 & 1 & 0 & 0 & 0 \\
\hline 12 & II & 1 & 0 & 1 & 1 & 0 & 1 & 1 & 1 & 0 & 0 & 1 & 1 & 1 & 1 \\
\hline 13 & AH & 1 & 0 & 1 & 1 & 0 & 1 & 1 & 0 & 0 & 0 & 1 & 0 & 1 & 1 \\
\hline 14 & Di & 1 & 0 & 1 & 1 & 0 & 1 & 1 & 0 & 0 & 0 & 1 & 0 & 0 & 1 \\
\hline
\end{tabular}


Fig 3 : Final reachability matrix

\begin{tabular}{|c|c|c|c|c|c|c|c|c|c|c|c|c|c|c|c|c|}
\hline S. & Barriers & 1 & 2 & 3 & 4 & 5 & 6 & 7 & 8 & 9 & 10 & 11 & 12 & 13 & 14 & D.P \\
\hline & & $\mathrm{CPP}$ & AMT & AT & DFNC & SIM & PFPP & PCIP & LTP & LoP & LP & WA & II & $\mathrm{AH}$ & $\mathrm{Di}$ & \\
\hline 1 & CPP & 1 & 0 & 1 & 1 & 0 & 1 & 1 & 0 & 0 & 1 & 1 & 1 & 1 & 1 & 10 \\
\hline 2 & AMT & 1 & 1 & 1 & 1 & 1 & 1 & 1 & 1 & 1 & 1 & 1 & 1 & 1 & 1 & 14 \\
\hline 3 & AT & 1 & 0 & 1 & 1 & 0 & 1 & 1 & 0 & 0 & 0 & 0 & 0 & 0 & 0 & 5 \\
\hline 4 & DFNC & 0 & 0 & 0 & 1 & 0 & 0 & 0 & 0 & 0 & 0 & 0 & 0 & 0 & 0 & 1 \\
\hline 5 & SIM & 1 & 1 & 1 & 1 & 1 & 1 & 1 & 1 & 1 & 1 & 1 & 1 & 1 & 1 & 14 \\
\hline 6 & PFPP & 1 & 0 & 1 & 1 & 0 & 1 & 1 & 1 & 1 & 1 & 1 & 1 & 1 & 1 & 12 \\
\hline 7 & PCIP & 1 & 0 & 1 & 1 & 0 & 1 & 1 & 1 & 1 & 1 & 1 & 0 & 0 & 1 & 10 \\
\hline 8 & LTP & 1 & 0 & 1 & 1 & 0 & 1 & 1 & 1 & 1 & 1 & 1 & 1 & 1 & 1 & 12 \\
\hline 9 & LoP & 1 & 0 & 1 & 1 & 0 & 1 & 1 & 1 & 1 & 1 & 1 & 1 & 1 & 1 & 11 \\
\hline 10 & LP & 1 & 0 & 1 & 1 & 0 & 1 & 1 & 1 & 0 & 1 & 1 & 1 & 1 & 1 & 11 \\
\hline 11 & WA & 1 & 0 & 1 & 1 & 0 & 1 & 1 & 1 & 1 & 1 & 1 & 1 & 1 & 1 & 11 \\
\hline 12 & II & 1 & 0 & 1 & 1 & 0 & 1 & 1 & 1 & 1 & 1 & 1 & 1 & 1 & 1 & 12 \\
\hline 13 & $\mathrm{AH}$ & 1 & 0 & 1 & 1 & 0 & 1 & 1 & 1 & 1 & 1 & 1 & 0 & 1 & 1 & 11 \\
\hline 14 & Di & 1 & 0 & 1 & 1 & 0 & 1 & 1 & 1 & 0 & 1 & 1 & 0 & 0 & 1 & 8 \\
\hline & De.P & 13 & 2 & 13 & 14 & 2 & 13 & 13 & 11 & 9 & 12 & 12 & 9 & 10 & 12 & \\
\hline
\end{tabular}

D.P : Driving power ; De.P : dependence power

\subsection{Level Partition}

From the final reachability matrix, reachability and final antecedent set for each factor are found. The element for which the reachability and intersection sets are same are the top-level element in the ISM hierarchy. After the identification of top level element, it is separated out from the other elements and the process continues for next level of elements. Iterations have been shown from table 3 - table 13 below

Table 4: Iteration I

\begin{tabular}{|c|c|c|c|c|}
\hline $\begin{array}{l}\text { S. } \\
\text { No }\end{array}$ & Reachability set & Antecedent set & $\begin{array}{c}\text { Inters } \\
\text { ection } \\
\text { set }\end{array}$ & $\begin{array}{l}\text { Le } \\
\text { vel }\end{array}$ \\
\hline 1. & 4 & $\begin{array}{c}1,2,3,4,5,6,7,8,9,1 \\
0,11,12,13,14\end{array}$ & 4 & \multirow{8}{*}{ I } \\
\hline 2. & $1,3,4,6,7$ & $\begin{array}{l}1,2,3,5,6,7,8,9 \\
10,11,12,13,14\end{array}$ & $1,3,6,7$ & \\
\hline 3. & $\begin{array}{c}1,3,4,6,7,10,11 \\
14\end{array}$ & $\begin{array}{c}1,2,5,6,7,8,9,10,1 \\
1,12,13,14\end{array}$ & $\begin{array}{c}1,6,7 \\
10,11, \\
14\end{array}$ & \\
\hline 4. & $\begin{array}{c}1,3,4,6,7,8,10,11 \\
14\end{array}$ & $\begin{array}{c}2,5,6,7,8,9,10,11 \\
12,13,14\end{array}$ & $\begin{array}{c}6,7,8, \\
10,11, \\
14\end{array}$ & \\
\hline 5. & $\begin{array}{c}1,3,4,6,7,8,10,11 \\
13,14\end{array}$ & $\begin{array}{c}2,5,6,8,9,10,11,12 \\
, 13\end{array}$ & $\begin{array}{c}6,8,10 \\
11,13\end{array}$ & \\
\hline 6. & $\begin{array}{c}1,3,4,6,7,8,10,11 \\
12,13,14\end{array}$ & $2,5,6,8,9,10,11,12$ & $\begin{array}{c}6,8,10 \\
11,12\end{array}$ & \\
\hline 7. & $\begin{array}{c}1,3,4,6,7,8,9,10, \\
11,12,13,14\end{array}$ & $2,5,6,8,9,11,12$ & $\begin{array}{l}6,8,9 \\
11,12\end{array}$ & \\
\hline 8. & $\begin{array}{c}1,2,3,4,5,6,7,8,9,1 \\
0,11,12,13,14\end{array}$ & 2,5 & 2,5 & \\
\hline
\end{tabular}

Table 5: Iteration II

\begin{tabular}{|c|c|c|c|c|}
\hline $\begin{array}{l}\text { S. } \\
\text { No }\end{array}$ & $\begin{array}{c}\text { Reachability } \\
\text { set }\end{array}$ & Antecedent set & $\begin{array}{c}\text { Intersec } \\
\text { tion set }\end{array}$ & $\begin{array}{l}\text { Le } \\
\text { vel }\end{array}$ \\
\hline 2. & $1,3,6,7$ & $\begin{array}{c}1,2,3,5,6,7,8,9,10 \\
11,12,13,14\end{array}$ & $1,3,6,7$ & \multirow{7}{*}{ II } \\
\hline 3. & $\begin{array}{c}1,3,6,7,10,11,1 \\
4\end{array}$ & $\begin{array}{c}1,2,5,6,7,8,9,10,11 \\
, 12,13,14\end{array}$ & $\begin{array}{c}1,6,7,10, \\
11,14\end{array}$ & \\
\hline 4. & $\begin{array}{c}1,3,6,7,8,10,11 \\
, 14\end{array}$ & $\begin{array}{c}2,5,6,7,8,9,10,11,1 \\
2,13,14\end{array}$ & $\begin{array}{c}6,7,8,10 \\
11,14\end{array}$ & \\
\hline 5. & $\begin{array}{c}1,3,6,7,8,10,11 \\
, 13,14\end{array}$ & $\begin{array}{c}2,5,6,8,9,10,11,12 \\
13\end{array}$ & $\begin{array}{c}6,8,10,1 \\
1,13\end{array}$ & \\
\hline 6. & $\begin{array}{c}1,3,6,7,8,10,11 \\
, 12,13,14\end{array}$ & $2,5,6,8,9,10,11,12$ & $\begin{array}{c}6,8,10,1 \\
1,12\end{array}$ & \\
\hline 7. & $\begin{array}{c}1,3,6,7,8,9,10 \\
11,12,13,14\end{array}$ & $2,5,6,8,9,11,12$ & $\begin{array}{l}6,8,9, \\
11,12\end{array}$ & \\
\hline 8. & $\begin{array}{c}1,2,3,5,6,7,8,9 \\
10,11,12,13, \\
14\end{array}$ & 2,5 & 2,5 & \\
\hline
\end{tabular}


Table 6 : Iteration II

\begin{tabular}{|c|c|c|c|c|}
\hline $\begin{array}{l}\text { S.N } \\
\text { o. }\end{array}$ & Reachability set & $\begin{array}{c}\text { Antecedent } \\
\text { set }\end{array}$ & $\begin{array}{c}\text { Intersect } \\
\text { ion set }\end{array}$ & $\begin{array}{c}\text { Lev } \\
\text { el }\end{array}$ \\
\hline 3. & $10,11,14$ & $\begin{array}{c}2,5,8,9,10,11 \\
, 12,13,14\end{array}$ & $10,11,14$ & III \\
\hline 4. & $8,10,11,14$ & $\begin{array}{c}2,5,8,9,10,11 \\
12,13,14\end{array}$ & $\begin{array}{c}8,10,11,1 \\
4\end{array}$ & \\
\hline 5. & $8,10,11,13,14$ & $\begin{array}{c}2,5,8,9,10,11 \\
12,13\end{array}$ & $\begin{array}{c}8,10,11,1 \\
3\end{array}$ & \\
\hline 6. & $\begin{array}{c}8,10,11,12,13 \\
14\end{array}$ & $\begin{array}{c}2,5,8,9,10,11 \\
12\end{array}$ & $\begin{array}{c}8,10,11,1 \\
2\end{array}$ & \\
\hline 7. & $\begin{array}{c}8,9,10,11,12,13, \\
14\end{array}$ & $2,5,8,9,11,12$ & $\begin{array}{c}8,9,11 \\
12\end{array}$ & \\
\hline 8. & $\begin{array}{c}2,5,8,9,10,11,12, \\
13,14\end{array}$ & 2,5 & 2,5 & \\
\hline
\end{tabular}

Table 7: Iteration IV

\begin{tabular}{|c|c|c|c|c|}
\hline $\begin{array}{l}\text { S. } \\
\text { No. }\end{array}$ & $\begin{array}{c}\text { Reachability } \\
\text { set }\end{array}$ & $\begin{array}{c}\text { Antecedent } \\
\text { set }\end{array}$ & $\begin{array}{c}\text { Intersection } \\
\text { set }\end{array}$ & Level \\
\hline 4. & 8 & $\begin{array}{c}2,5,8,9,12 \\
13\end{array}$ & 8 & \multirow[t]{5}{*}{ IV } \\
\hline 5. & 8,13 & $\begin{array}{c}2,5,8,9,12 \\
13\end{array}$ & 8,13 & \\
\hline 6. & $8,12,13$ & $2,5,8,9,12$ & 8,12 & \\
\hline 7. & $8,9,12,13$ & $2,5,8,9,12$ & $8,9,12$ & \\
\hline 8. & $2,5,8,9,12,13$ & 2,5 & 2,5 & \\
\hline
\end{tabular}

Table 8 Iteration $\mathrm{V}$

\begin{tabular}{|c|c|c|c|c|}
\hline $\begin{array}{c}\text { S. } \\
\text { No. }\end{array}$ & $\begin{array}{c}\text { Reachability } \\
\text { set }\end{array}$ & $\begin{array}{c}\text { Antecedent } \\
\text { set }\end{array}$ & $\begin{array}{c}\text { Intersection } \\
\text { set }\end{array}$ & Level \\
\hline 6. & 12 & $2,5,9,12$ & 12 & \multirow{2}{*}{ V } \\
\cline { 1 - 4 } 7. & $\mathbf{9 , 1 2}$ & $2,5,9,12$ & 9,12 & \\
\cline { 1 - 3 } 8. & $2,5,9,12$ & 2,5 & 2,5 & \\
\cline { 1 - 3 }
\end{tabular}

Table 9 Iteration VI

\begin{tabular}{|c|c|c|c|c|}
\hline $\begin{array}{c}\text { S. } \\
\text { No }\end{array}$ & $\begin{array}{c}\text { Reachability } \\
\text { set }\end{array}$ & $\begin{array}{c}\text { Antecedent } \\
\text { set }\end{array}$ & $\begin{array}{c}\text { Intersection } \\
\text { set }\end{array}$ & Level \\
\hline 8. & $\mathbf{2 , 5}$ & 2,5 & 2,5 & VI \\
\hline
\end{tabular}

\subsection{ISM model}

An ISM model is developed ( as shown in fig. 5 below ) after arranging the elements as per their interaction or dependence relationships.

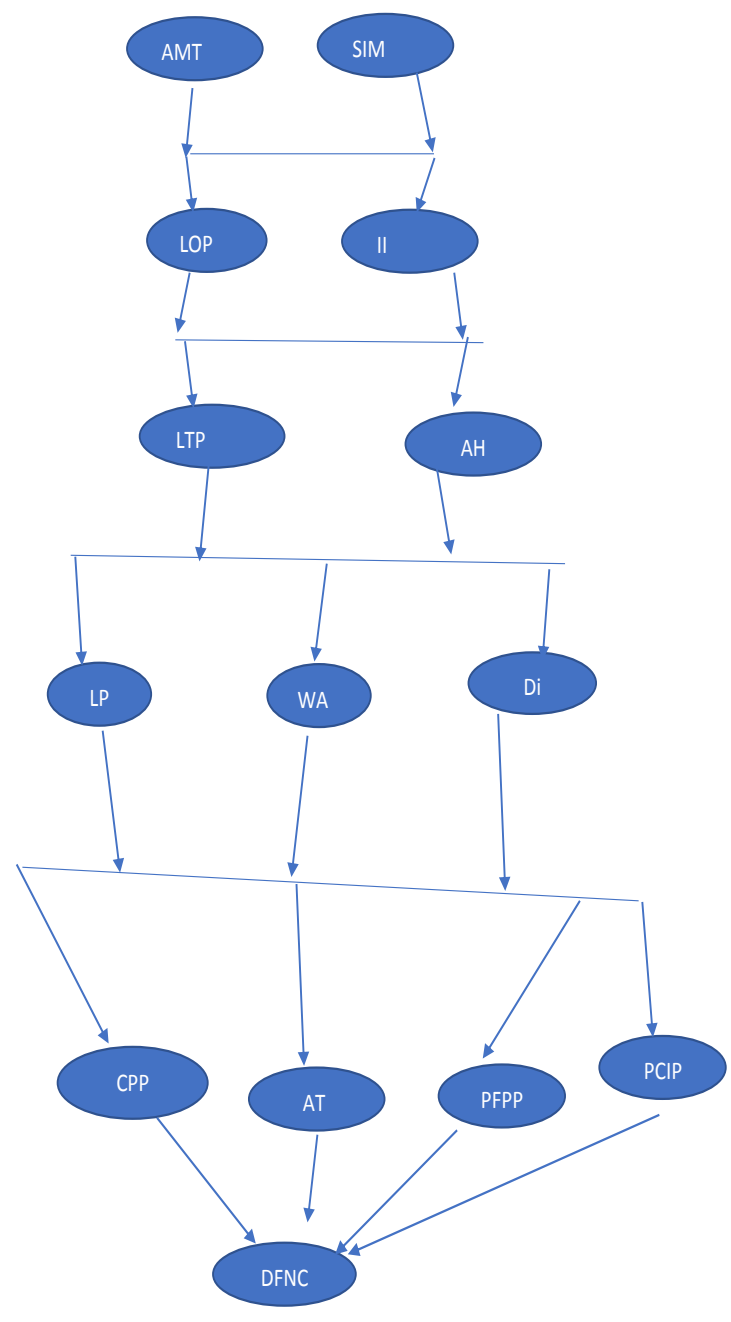

Fig 5 : ISM Model

\section{MANAGERIAL IMPLICATIONS \& CONCLUSIONS}

This section focuses on the various managerial implications which are described as follows :

- The commercial market of professional photography could be frustrating to the photographers but it doesn't likely harm them significantly from a business standpoint which is the reason why many professional photographers has declined to take significant action against noncommercial image sharing.

- While consumers do buy photos, they typically purchase prints, not digital downloads. Those who buy digital downloads of images usually are looking to do something with them, whether it is to use it on a commercial website or in a brochure. What this means is that, while the widespread sharing of photos might be difficult for some photographers to watch, it could be a significant opportunity as well.

\section{ACKNOWLEDGMENTS}

Our thanks to the anonymous reviewers whose comments have helped us in improving the manuscript .The writers deeply acknowledges the effort of photographers, Indian Bollywood industry have. They are the backbone of any 
actor's career. Credit also goes to our photogenic face acting stars. They are the actually a stress reliever for the photographers.

\section{REFERENCES}

[1] https://www.plagiarismtoday.com/2013/01/16/thechallenge-faced-by-photographers/

[2] https://www.digitalphotomentor.com/photographychallenges/
[3] https://www.naturettl.com/7-challenges-all-landscapephotographers-must-overcome/

[4] https://sleeklens.com/challenges-faced-as-a-freelancephotographer-how-to-overcome-them/

[5] Warfield, J. N. 1974. Developing interconnection matrices in structural modeling. IEEE Transactions on System, Man, and Cybernetics, SMC-4 (1), 81-87. 